be decided by actual examination of my published fapers on symbolical logic, of which Prof. Jevons has very kindly given in NATURE a full and complete list.

73, Rue Siblequin, Boulogne-sur Mer, April 7

\section{Agricultural Communism in Greece}

The article in NATURE, vol. xxiii. p. 525, on Aryan villages and other Asiatic communities reminds me of what I saw in r843 in the course of a journey through Greece. On St. George's Day, a high festival with the Greek peasants, when crossing the range of Mount Cithreron between Thebes and Eleusis, I saw my companion, who was about half a mile ahead, surrounded by a number of men, and then pulled from his horse. The man we had engaged as interpreter, guide, and protector, the "dragoman," bolted as a matter of course, thinking we had fallen upon a nest of brigands; but when I reached the scene of action I was surprised to find that the yelling and uproar heard in the distance were not murderous nor at all malignant, but purely hilarious. I was dragged from my horse also, and surrounded by about twenty young fellows with shaven heads and long scalp locks, half stripped, half drunk, and very dirty, but perfectly good-humoured.

We were presently made to join in a wild dance, a survival of the Pyrrhic dance of antiquity, which we improved very successfully ; my companion, C. M. Clayton, from Delaware, doing a nigger break down and I the sailor's hornpipe.

On the final arrival of our dragoman we learned that the twenty young men were brothers, and that the old man with long white beard who sat gravely looking on and playing a sort of tom-tom to tune the dance was their father. On our expressing surprise at so large a family of sons being so nearly of the same age he explained that $\alpha \delta \in \lambda \phi o ́ s$ did not always signify a blood relation, and that these were merely agricultural brethren. They were the united proprietors or renters (I do not remember which) of the adjoining farmhouse and the surrounding land, which they cultivated under the direction of the old man whom they had selected as their father, who was entrusted with the custody and division of their capital and profits, who arbitrated in cases of quarrels, and was otherw ise obeyed in most things.

Here was a patriarchal form of communism that we afterwards met with in several other instances, but in this and the other cases it was limited to young unmarried men. There were no women in the dance and none visible on this farm, which was some miles distant from the nearest village, Platæa.

At that time the Klephts, or brigands, were united in similar communities, who sternly abjured all communication with the fair sex.

When we had finished our dance and paid for sufficient wine to go round the family circle we found that before going we must kiss all the brothers or give mortal and dangerous offence. Andrew, our dragoman, with the inventive facility of his nation, extricated us from this by solemnly stating that in England it was an established custom to show respect for a family by embracing the father only, and bowing separately to each of the sons.

I am unable to supply any further particulars concerning the internal economy of these communities, cannot say whether they prevail chiefly among the Greeks or the Albanians (the latter constitute a large proportion of the agricultural population of Greece), nor how they dissolve when the brothers become married or the father dies. I have met with no account of them in the course of my reatling, but am not at all surprised at this, seeing how profound is our general ignorance of everything pertaining to Greece, an ignorance which is most glaringly displayed by political writers and others, who speak of Athens as though it were Greece, and of Athenian proceedings as though they were the action of the Greeks.

But for the accident of this rather startling festive encounter with these brethren on this particular holiday, we might have travelled for weeks without meeting any visible indications of such fraternities. We should have passed the brothers if they were working in the fields, and the patriarch had he been sitting alone at the farmhouse door, without special notice. It was only after our curiosity had been excited that we discovered otber patriarchs and other brethren by special inquiry where their existence was vaguely indicated.

Among the readers of NATURE there may be some who have sufficient acquaintance with the Greek people, outside of Athens, to be able to supply interesting particulars concerning these curious communities. They may be survivals of our ancient communism, or a modern device for mutual protection forced upon the rural population by the absence of any enforcement of law and social order by those who consume the taxes in Athens. W. Mattieu Williams

\section{Heat of Stellar Masses}

I SEND you a working hypothesis which I think will well pay for its place in the world. It is as to the heat of large stellar masses ; that the imperfect conduction of the kinetic force producing gravitation through large stellar masses causes heat in them.

The quantity of heat stored up may decend partly on the proportion of mass to radiating power, and partly, perhaps, on the condition of the mass for such conduction.

Washington, D. C., March 25

Saml. J. Wallace

\section{Shadows Cast by Venus}

ON March $2 \mathrm{r}$ last, about 8 p.m., I was walking among some trees by a river's bank. The ground was covered with recently. fallen snow, and the shadows of the trees were unmistakably, though faintly, traceable on the white surface. The night was dark and the shadows were thrown by Venus, which was shining with unusual brilliancy. I believe this obvious form of the phenomenon is not a common one in our latitude.

3I, Havelock Street, Sheffield, April is Chas. T. WhitMell

\section{The Sparrow and Division of Labour}

THE following curious fact may possibly interest your ornithological readers:-Last year and the year previous two pairs of swallows made their nests and successfully reared their broods under the eaves of my house. Within the past fortnight a brace of astute London sparrows have apparently recognised the principle of division of labour as applicable to their requirements in the art of nest-building. They have selected the largest and most substantial of the swallows' nests referred to; and, after devoting a day or two, on starting on their enterprise, to the enlargement of the entrance hole, which was probably too narrow for them, have constructed their bed within of bits of grass and feathers in the usual fashion. They are now enjoying their honeymoon in their new quarters.

3, Christchurch Road, Roupell Park, April ir G. C. WALLICH

\section{SIR PHILIP DE MALPAS GREY EGERTON, M.P., F.R.S.}

I N Sir Philip Egerton geologists have lost one of that band of workers who placed their science upon the footing which it now occupies in this country. Unfortunately that band has been of late years greatly diminished by death. Born in 1807 , Sir Philip Egerton with his old friend and fellow-worker, Lord Cole (now the Earl of Enniskillen), while still at Oxford commenced the collection of fossils, and very soon their attention was especially directed to fossil fish, of which but very little was at that time known. As specimens of this group of organisms often occur in duplicate, the individuals breaking across so that two opposite slabs each contain one-half, the two friends agreed to share their spoils, and thus both collections were enriched. When in 1840 Agassiz visited this country, intent upon his great ichthyological memoirs, he found in the museums of Sir Philip Egerton and Lord Cole an abundance of materials ready to his hand. The specimens were carefully figured, and descriptions of them included in the several great works which Agassiz successively issued. The original drawings by Dinkel are now among the archives of the Geological Society. But Sir Philip Egerton was by no means merely a collector of fossils, he was a very diligent and successful student of ichthyology. Many valuable papers on fossil fishes were written by him at different times, and a series 